\title{
NAPHTAS RET - OM KRISTENDOMMENS BIDRAG TIL DEN MODERNE VELFÆRDSSTAT*
}

\author{
Anders Klostergaard Petersen
}

Den som nøye vil anatomere den menniskelige Sjæl skal finde, at den Hoved-Seene, som giver den al sin følelse og virksomhed, er Egenkjærlighed.

J. Ewald

\begin{abstract}
ENGLISH ABSTRACT: This essay examines the extent to which EvangelicalLutheran Christianity may contribute to the maintenance of social coherence in the current Danish welfare state. The secular doctrine of a principal separation of politics and religion is emphasised as a premise for the discussion. It is argued that the system on which the welfare state is founded has been developed by a process of secularisation of Christian ideal values, particularly the idea of love of the neighbour. In compliance with the Danish theologian and philosopher Løgstrup, it is claimed that the basic values of the Danish welfare state may be seen as a reduction of Christian ideals to the general idea of the Golden Rule implemented at the societal level. The welfare state as a system is vulnerable since it is predominantly founded on symbolic communication and, additionally, it is forced to be self-referential in its arguments. In this context Christianity may contribute to the coherence of the system by anchoring its basic values in an interpretative frame that excludes relativisations.
\end{abstract}

DANSK RESUME: Artiklen drøfter, i hvilken forstand og under hvilke prcemisser kristendommen - i skikkelse af evangelisk-luthersk kristendom - kan siges at bidrage positivt til den moderne danske velfordsstats sammenhongskraft. Den principielle adskillelse mellem religion og politik fremhoeves som et gode, ligesom der argumenteres for, at det system, velfardsstaten bygger på, er blevet til gennem en sekularisering af et kristent vordiunivers. Det pointeres, at velfardsstaten som system er sårbar, dels fordi den grundlaggende bygger på symbolsk kommunikation, dels fordi den ikke har andet end sig selv at henvise til. I den sammenhoeng fremhoeves det, at religion - i konteksten evangelisk-luthersk kristendom - kan bidrage positivt til velfcerdsstaten, fordi den supplerer de basale principper og vardier, velfcerdsstaten er bygget op om, ved at forankre dem $i$ en religiøs tydning, der ikke tillader relativeringer.

KEY WORDS: Danish welfare state; Christianity's contribution to the welfare state; reciprocity; social coherence; secularism, Løgstrup, the Golden Rule.

\footnotetext{
* Jeg har valgt at bevare oplæggets oprindeligt mundtlige form. Af samme grund har jeg også valgt at begrænse antallet af noter og henvisninger til videnskabelig litteratur til et minimum. Mit essay er ment som et debatoplæg.
} 
Om end Eli Naphtas skikkelse er tegnet med sympatiske strøg, er og bliver han en spejling af Thomas Manns ressentiment over for jødedom og katolicisme: En jødisk konvertit til den, set med nordtyske, senatoriale øjne, mest rabiate del af romerkirken: Jesuiterordenen. Her får den protestantiske lübecker let spil til (lidt provinsielt) at udfolde sin mangel på forståelse og sin fremmedhed over for verden syd for Hamburg. Ganske vist er også humanisten Settembrini skildret i en stereotypiserende gengivelse af lidenskabeligt sydlandsk væsen, ligesom der bag portrættet ligger en ætsende persiflage af den dannelses- eller civilisationslitterat, som Mann også anså for en stor fare for demokratiet; men Naphta er ham ikke en værdig modstander. Dertil er Settembrini ham for overlegen. I det omfang man overhovedet kan tale om sympati hos forfatteren for nogen af de to skikkelser, ligger den hos humanisten og ikke hos religiøsitetens advokat.

Mit bidrag til denne diskussion om forholdet mellem kristendom og velfærdsstat genoptager dialogen fra Zauberberg, idet jeg lader Naphta erstatte med en køligt vurderende, rationelt distanceret, nøgtern protestantisk gestalt i skikkelse af mig selv og i øvrigt forlægger scenen til det danske fladland. Dermed bliver, vil jeg hævde, konflikten mellem de to verdenssyn betydeligt mere accentueret, fordi det netop gennem de seneste århundreder har været den evangelisk-lutherske protestantismes adelsmærke at have internaliseret spændingen mellem disse to strømninger (Petersen 2005a, 129). På den ene side en sekulær, humanistisk diskurs, der gennem en lang periode, kulminerende med den moderne religionskritik i skikkelse af Nietzsche, Marx og Freud, endegyldigt løsrev sig fra den klassiske oplysningstænknings forsøg på at befri det religiøse verdensbillede for dets mest 'absurde' træk og at grunde etikken i alment forpligtende forestillinger, for i stedet at tale ud fra et bevidst ikke-religiøst verdenssyn. På den anden side en religiøs diskurs formuleret inden for rammerne af et kontaktunivers, ${ }^{1}$ hvis fysiske verden - sat på spidsen - forudsætter tilstedeværelsen af transhumane agenter: Gud, Kristus og Helligånden ikke kun som kulturelle fortolkninger, men som tilgængelige størrelser i verden. Man kan naturligvis, som det er sket i megen moderne protestantisk kristendom, søge at nedtone denne dimension gennem et opgør med en klassisk teisme, men helt borteliminere den kan man ikke. Så længe man vil fastholde kristendom som religion sensu stricto, er den netop kendetegnet ved at repræsentere en verdenstolkning, der på et eller andet niveau forudsætter tilstedeværelsen af transhumane aktører i kontaktuniverset. ${ }^{2}$

\footnotetext{
${ }^{1}$ Begrebet 'kontaktunivers' stammer fra Johansen og Larsen (1994, 212.290), som anvender det i forlængelse af Karl Bühler til at betegne det fysiske rum, i hvilket tegnbrugere, tegn og reference på samme tid er til stede og er forbundne. Enhver kultur konstruerer et kontaktunivers, der samtidig er en refleksion af den pågældende kulturs virkelighedsforståelse. Det siger noget om, hvordan man i den pågældende kultur lokaliserer og afgrænser forskellige fænomener i tid og rum. Mens hekse i en kultur forstås som integreret del af kontaktuniverset, hvor de opfattes som lige så virkelige som andre fænomener i det fysiske rum, placeres de $i$ en anden kultur uden for kontaktuniverset som fantasivæsener og udtryk for overtro, men som tolkning naturligvis inden for kulturen.

${ }^{2}$ Jf. Geertz $(1996,126)$, der definerer religion som "et kulturelt system og en social mekanisme (eller institution), som styrer og fremmer idealfortolkningen af tilværelsen og idealpraksis ved henvisning til en eller flere transempiriske magter."
} 
Det er på baggrund af denne protestantiske tradition, der rummer en, vil jeg hævde, 'balkanistisk' bevidsthed om til stadighed at pendulere mellem forskellige virkelighedsrepræsentationer med dertil hørende forskellige kontaktuniverser, at jeg ønsker at rejse spørgsmålet om Naphtas ret eller en evangelisk-luthersk kristendoms bidrag til den moderne velfærdsstat. ${ }^{3}$ Mit spørgsmål er i virkeligheden meget enkelt. Kan kristendommen overhovedet bidrage til den moderne velfærdsstat, der blandt andet er blevet til som et resultat af en principiel adskillelse mellem politik og religion? Hvis velfærdsstaten er funderet på en sekulær doktrin, der foreskriver, at religion og politik i princippet bør holdes adskilt, giver det da mening at stille spørgsmålet om kristendommens bidrag til velfærdsstaten? Er det ikke blot et forsøg på at genindføre religionen i en sfære, hvor den ikke længere hører hjemme? Hvis det, som det blandt er blevet fremhævet af Løgstrup (1996, 50f), gælder, at den moderne velfærdsstat som samfundsorden forudsætter en nedskrivning af moralen til samfundsbrug, giver det da mening at spørge til den ideale morals bidrag til den nedskrevne? Kan kristendommens fremhævelse af næstekærlighedsbuddet have positiv betydning for et samfund, der har nedskrevet den radikale fordring til en politisk ide om, at samfundet skal indrettes, så borgerne bærer sig ad, som om de elskede næsten, vel vidende at de ikke gør det? (Løgstrup 1996, 54). Det vil jeg mene, men det forudsætter en række mellemregninger.

\section{Fra Naphta til i dag - de ånds- og socialhistoriske forudsætninger for diskussionen}

Før jeg reorkestrerer Naphta og Settembrinis dialog, er jeg nødt til at præcisere enkelte præmisser som forudsætning for min traditionsfrasering. For det første vil det i dag være absurd - med en af Dostojevskijs figurer at hævde - at "dersom Gud ikke eksisterer, er alt tilladt". Ingen kan i dag meningsfuldt bestride, at såvel ateister som agnostikere selvsagt kan handle etisk efterstræbelsesværdigt, så lidt som det kan hævdes, at religiøse mennesker skulle være ikke-religiøse etisk overlegne. Problemstillingen kan ikke reduceres til en modsætning mellem en religiøs og en ikke-religiøs verdenstydning. Ej heller kan den forsimples til en modstilling mellem kristendom og andre former for religion eller for den sags skyld gøres til en konfessionel kontrast mellem evangeliskluthersk og andre former for kristendom (jf. Petersen 2005b, 547-9). Historien viser til fulde, at religion eller kristendom ikke i sig selv er garant for etisk efterstræbelsesværdig handlen. Den kan være det, men behøver det ikke. I den forstand deler jeg den tidligere italienske justitsminister Claudio Martellis synspunkt, som det kommer til udtryk i en essaysamling In cosa crede chi non crede?, der er en pendant til diskussionen mellem Naphta og Settembrini, her i skikkelse af en dialog mellem Umberto Eco og Milans kardinal Carlo Maria Martini. Martelli hævder - i min oversættelse -:

\footnotetext{
${ }^{3}$ Begrebet 'balkanisering' til betegnelse af evnen til simultant at tro på indbyrdes forskellige virkelighedsrepræsentationer stammer fra den franske filosof Paul Veyne $(1983,67)$, som imidlertid formulerede det, før konflikterne brød ud på Balkan i 1990'erne. For en udfoldelse af begrebet i sammenhæng med drøftelsen af forholdet mellem tro og fornuft, se mit essay 2005a.
} 
For at opnå en anden synsvinkel, må vi i det mindste forudsætte, at sondringen mellem laizister og katolikker, troende og ikke-troende - i overvejende grad og for langt de fleste menneskers vedkommende, i det mindste i Vesten - ikke udgør en afgrundsdyb kløft, men snarere en flydende grænse, og netop en, der ikke alene løber mellem os og de andre, men først og fremmest også i os selv (Martelli 2003, 128).

Dertil kommer, at jeg i dette essay alene er optaget af at se på kristendommens mulige bidrag til at understøtte den adfærd og handlen, der er forudsætning for, at den moderne, danske velfærdsstat kan fungere. Fokus er derfor rettet mod de helt basale adfærdsnormer og bevæggrunde, som udgør grundstammen for velfærdsstatens sociale kohærens, dvs. næstekærlighedsbuddet og den gyldne regel nedskrevet til politisk ide i samfundsindretningen.

For det andet er der en afgørende forskel mellem Thomas Manns iscenesættelse af konflikten og min aktualiserede dramaturgi. Hvor den i Zauberberg udspilles inden for det sandes domæne, vil jeg - uden her at kunne gå nærmere ind på en argumentation, jeg har udfoldet i anden sammenhæng (Petersen 2005b, 546f) - hævde, at den i dag primært må drøftes i relation til det godes og det skønnes domæner, dvs. inden for et etisk og et æstetisk register. Diskussionen kan ikke som i duellen mellem Settembrini og Naphta føres i absolutte kategorier, men må antage en mindre prætentiøs form. Et absolut sandhedsbegreb, der ville indebære en videnskabelig mulighed for at efterprøve en given religions påstande om at repræsentere den virkelige virkelighed, må vige for den mindre fordringsfulde diskussion af bestemte religiøse verdenstydningers etiske bonitet og æstetiske kompleksitet. Det betyder ikke, at et sandheds- og normativitetsaspekt lades ude af betragtning. Det indskrænkes imidlertid til alene at blive drøftet i sammenhæng med det skønne og det gode.

For det tredje forudsætter jeg i min diskussion den type samfundsdannelse, som vi har set udvikle sig i Nordvesteuropa fra efterkrigstiden og frem. Udgangspunktet er en samfundsform, hvor der principielt hersker en adskillelse mellem det religiøse og det politiske domæne. Jeg vil gerne understrege min brug af ordet principiel, fordi der hverken er tale om nogen statisk eller klart afgrænset fordeling af magten mellem de to sfærer. Vi kan tværtimod se, hvordan der gennem hele perioden har foregået og til stadighed foregår kampe og forhandlinger mellem forskellige grupper og enkeltpersoner om, hvordan relationen mellem det politiske og det religiøse bedst udmøntes i praksis. De varierende opfattelser strækker sig fra ønsket om en radikal adskillelse af de to felter fra hinanden til forsøg på at opnå en større grad af synergi mellem dem i form af øget religiøs indflydelse i det politiske rum. Det er også en præmis for min argumentation, at udviklingen i retning af forskellige - relativt - autonome sektorer har været til gavn såvel for den almene samfundsudvikling som for Folkekirken. Opdelingen i forskellige rum modsvarer på et samfundsmæssigt plan de grænsedragninger og skillelinier, vi på et individuelt niveau kan iagttage som forskellige virkelighedsrepræsentationer. En skarp sondring mellem det verdslige og det åndelige regimente er et gode, som hverken kirken eller andre religiøse institutioner kan omstøde, uden derved at gøre ubodelig skade for sig selv og samfundet. Den adskillelse, vi i Danmark kender mellem religion og politik, 
kan lignes med det checks and balances-system - institutionaliseret i det amerikansk politiske system, hvor de forskellige politiske organer holder hinanden i skak, så den ene ikke tilraner sig uretmæssige magtbeføjelser. Kirken er en moralsk linievogter, der med Søren Ulrik Thomsens formulering i essayet Fornuft og mysterium:

skal tugte magten og relativere politikken, så ingen magthaver fristes til at tro, at han er Gud, og ingen politik bilder sig ind at kunne skabe en fuldkommen verden. Omvendt skal adskillelsen mellem de to sikre, at religionen ikke får politisk magt, for den er 'kun til indvortes brug', og vil den fra prædikestolen altid have et ord at sige mennesket om de grundvilkår, det til alle tider og i et hvilket som helst samfund har delt med alle andre, skal den dog, lige så lidt som staten bør blande sig i borgernes tro, have nogen mening om finanslovsforslaget eller byens nye idrætshal, men give kejseren, hvad kejserens er, og Gud, hvad Guds er $(2005,116)$.

Hermed henvises det religiøse ikke nødvendigvis alene til den private sfære. Kirken eller for den sags skyld andre religiøse institutioner kan, netop fordi de ikke er en del af den politiske sfære tage del i den offentlige debat som et samfundskritisk element, der kan holde politikken fast på de civilisatoriske standarder og grundlæggende menneskerettigheder, som er fælles for alle borgere. Kirken kan selvsagt ikke afkræve det politiske system en urealistisk udmøntning af ideale kristne værdier i samfundsindretningen - det ville være udtryk for et sværmeri, der ikke respekterede adskillelsen mellem politik og religion eller forskellen mellem ide og absolut fordring. Omvendt hindrer det ikke, at kirken kan have en vigtig rolle som kritisk instans, der som bærer af et politisk uafhængigt værdiunivers kan være en stadig udfordring til den realpolitiske verden. Forudsætningen er, at kirken er sig den sekulære diskurs’ spilleregler bevidst, fordi et politisk system aldrig kan føle sig forpligtet på, endsige realpolitisk efterkomme de absolutte fordringer, kirken i sin forkyndelse retter til den enkelte troende. Kirken kan f.eks. ikke, som fremhævet af Løgstrup, af det politiske system kræve, at det skal indrette samfundet ud fra en fuldbyrdet efterlevelse af næstekærlighedsbuddet (1996, 51-3); men den kan kritisere elementer i aktuel lovgivning og samfundsindretning for ikke i tilstrækkelig grad at honorere den gyldne regel som samfundspolitisk ide, ligesom dens absolutte fordring til den enkelte kan være en kilde til selvkritik i det politiske system. Det vender jeg tilbage til.

\section{Velfærdsstaten som kulturlig størrelse: En skrøbelig konstruktion}

Med dette udgangspunkt kan vi fokusere på den aktuelle velfærdsstat og dens troværdighedsproblemer. Som kulturlig - ikke naturlig - størrelse er velfærdsstaten underlagt de problemer, der truer alle kulturelle konstruktioner. Den er i sit væsen skrøbelig, fordi den alene har bæredygtighed i kraft af en bestemt fortolkning med en dertil hørende praksis. Man kan diskutere, hvor naturlige familier i grunden er. De kan - til trods for en vis grad af naturlighed knyttet til fælles genetisk komposition - opløses, ligesom det tilfældige valg af partner peger på et element af vilkårlighed. Men når det drejer sig om kulturelle størrelser som nationer, større samfundsdannelser eller religioner, er der ingen 
tvivl. Uanset deres selvforståelse er de kulturlige konstruktioner, uden at jeg dermed har sagt noget om deres korrelat til en bagvedliggende virkelighed. Med anvendelsen af begrebet konstruktion ønsker jeg alene at fremhæve de sociale og kulturelle betingelser, enhver gruppedannelse er underlagt.

Som kulturlig størrelse er den danske velfærdsstat skrøbelig. Den har kun eksistens under forudsætning af, at borgerne genkender sig i dens verdensbillede og er villige til tilnærmelsesvis at følge de adfærdsregler, den 'foreskriver'. Billedligt kan man sammenligne den med en membran, hvis midte udgøres af de kosmologier, institutioner, regler og værdier, der giver membranen fylde. De reificeres i en grad, så de fremstår lige så virkelige som den omgivende natur. Det er ikke mindst i kraft af dem, at mennesker kan orientere sig i tilværelsen og indgå i relationer til andre mennesker. Kort sagt, det vi normalt kalder et samfund. Ikke desto mindre har de som kulturlig konstruktion også en betydelig skrøbelighed. De har meningsfylde og bærekraft, så længe mennesker kan genkende sig i deres tydningsunivers og er villige til at tilslutte sig det; men udfordres deres plausibilitet, trues de af opløsning og tilintetgørelse. Den membranale periferi er sårbar, fordi bevægelser i grænseområderne truer med at punktere membranen, ligesom en øget afstand mellem midte og periferi forøger risikoen for membranal sprængning.

Hvis velfærdsstaten som kulturlig størrelse alene har eksistens i kraft af de enkelte borgeres tilslutning, er den udsat for to grundlæggende risici, som truer alle kulturelle konstruktioner, der hviler på symbolsk kommunikation. ${ }^{4}$ Symbolsk kommunikation gør det på den ene side muligt at overskride talens her og nu, men det skaber på den anden side problemer knyttet til tillid, sanddruhed, tiltro, etc. For det første er der risikoen for Babel, hvor ordene bliver så polyvalente og signifianterne så flydende, at betydningsuniverset trues af sprængning. Man ved ikke længere, hvad talen betyder, og kan derfor heller ikke fæste lid til den. For det andet, og langt mere relevant for drøftelsen af den moderne velfærdsstats problemer, er der risikoen for løgn og bedrag eller udsigten til at blive snydt.

Den talendes udsagn vil altid og i særdeleshed, når der henvises til aktuelle tilstande, være underkastet modtagerens vurdering af, om udsagnet står til troende eller ej. Hvordan kan man som borger fæste lid til, at de værdier, man afgiver til gruppen, også vil komme en selv til gode, at de vil blive returneret - et ikke helt uvæsentligt problem, når man tager sin skattebetaling i betragtning? Hvordan kan man som borger $\mathrm{i}$ velfærdsstaten nære tiltro til, at de løfter, der er blevet givet, også ad åre vil blive indfriet? Tænk en gang, hvis den andel af ens løn, der månedligt inddrages til opsparing med den fremtidige pension for øje, på et tidspunkt blev inddraget af staten, fordi landet momentant standede $\mathrm{i}$ våde og derfor havde brug for en akut pekuniær saltvandsindsprøjtning? Tænk på alle eksemplerne på brud på 'berettigede forventninger'. Skal en kulturlig konstruktion som velfærdsstaten ikke trues af tilintetgørelse, må dens enkeltmedlemmer dels kunne nære fundamental tillid til den symbolske kommu-

\footnotetext{
${ }^{4}$ For en grundlæggende drøftelse af problemer knyttet til den symbolske kommunikation, se Rappaport 1999, 7-22.54f.
} 
nikations pålidelighed, dels kunne fæste lid til symboluniversets troværdighed. Det er da også derfor, det i den aktuelle danske politiske situation er så vanskeligt for politikerne gennem reformer at foretage større indgreb i velfærdssystemet, fordi det af mange borgere opfattes som et brud med systemets symbolske orden. Et indgreb i efterlønnen f.eks. forstås som sacrilegium, et blasfemisk brud på værdiuniversets hellige orden.

\section{Reciprocitet og værdiudveksling}

Tilliden til den symbolske kommunikation gælder naturligvis også i det nære forhold, hvor der i udvekslingen af gaver eller ord altid vil være en forventning om, at udvekslingens værdigoder ækvivalerer forholdet mellem de udvekslende parter (jf. Petersen 2004, 260-2). Det er helt legitimt, at der i forbindelse med f.eks. udveksling af jule- eller fødselsdagsgaver hersker en pekuniær asymmetri i forholdet mellem børns og forældres gavegivning, fordi de to parter befinder sig i et socialt asymmetrisk forhold til hinanden. Derfor tager jeg med glæde imod et bemalet syltetøjsglas fra mit barn, mens jeg omvendt betaler symbolsk tilbage med en eksorbitant gave. En sådan asymmetri skaber imidlertid social forlegenhed og bryder et kulturelt tabu, hvis den bringes $\mathrm{i}$ anvendelse mellem i udgangspunktet symmetriske parter som f.eks. i venskabsrelationen. Der skal helst herske ækvivalent reciprocitet i udvekslingen af værdiobjekter, når det gælder symmetriske relationer. Det vender jeg tilbage til.

Der består imidlertid den afgørende forskel i værdiudvekslingen i det nære forhold, som hersker mellem venner og i familien, og den, der finder sted i større gruppedannelser som f.eks. velfærdsstaten, at relationen mellem de udvekslende parter i store sociale grupper er anonymiseret. Der hersker heller ikke nødvendigvis en direkte sammenhæng mellem ydelse og nydelse, ligesom der ikke kan være tale om et simpelt do ut des-forhold, fordi udvekslingerne i kraft af systemets kompleksitet er blevet afpersonificeret og institutionaliseret (jf. Løgstrup 1996, 55f). Dertil kommer, at man som enkeltindivid i sit livsløb befinder sig i forskellige situationer i forhold til samfundet (jf. Jørn Henrik Petersens bidrag i dette nummer). I perioder er man skatteyder, mens man i andre er skattenyder. Som skatteyder er det væsentligt at have for øje, at man som barn og ung har været og igen som pensionist vil være skattenyder, og at det derfor er ganske rimeligt, at man også selv yder sit bidrag. Omvendt er man som skattenyder forpligtet på at erindre sig sammenhængen mellem ydelse og nydelse. Man kan som skattenyder ikke stille urimelige krav uden at være sig omkostninger og finansiel belastning bevidst. Det er alt sammen udmærket og ræsonnabelt, selv om det stiller krav til den enkelte om altid at holde sig selverkendelsens kritiske radikalitet for øje. Noget som øjensynligt vanskeliggøres af det forhold, Jørn Henrik Petersen i essaysamlingen Vandringer $i$ velfcerdsstaten sardonisk har spiddet:

Min nabos ydelser reduceres ikke, fordi jeg søger min fordel, og hans skat stiger ikke, fordi jeg tilraner mig et lidt større fradrag. Jeg spiller ikke mod min nabo. Han er blevet anonym for mig og jeg for ham. For hvis vi alle sammen snyder sådan ca. lige meget, går det jo ikke ud over nogen - eller hvad? $(1996,88)$. 
Sort arbejde f.eks. opleves næppe af den enkelte som et voldsomt overgreb på velfærdsstatens symbolunivers, men det er ikke desto mindre en aktivitet, der undergraver velfærdsstatens økonomiske grundlag. Den enkelte kan legitimere sin brug af sort arbejde gennem kritik af et system, der stiller 'urimelige' krav til ham eller hende, men overser, at systemmisbrug også er til skade for ens nærmeste. Frem for at se systemet som et gode, der sikrer, at alle kan oppebære en tålelig økonomisk eksistens, opleves det som et indgreb i ens egne handlemuligheder. Jo mere en sådan opfattelse vinder frem, desto mere trues velfærdsstaten af indre opløsning. Dertil kommer, at det som fremhævet af Jørn Henrik Petersen - er afgørende at være opmærksom på, at ens aktuelle situation ikke kan tænkes løsrevet fra de faser, man i øvrigt tidligere har befundet sig i og fremtidigt vil befinde sig i. Der er en tæt sammenhæng mellem ens aktuelle ydelse og den nydelse, man $i$ andre faser har oppebåret og vil oppebære. Er det muligt hos de fleste at fremelske en forståelse, der sætter dem i stand til at sammentænke deres øjeblikkelige situation med de livsfaser, de i øvrigt har befundet og vil befinde sig $i$, kompliceres billedet unægtelig af, at tingene i velfærdsstaten - til forskel fra den direkte reciprocitet - ikke går op, når det endelige regnebræt skal opgøres. Den enkelte borgers samlede skattebetaling vil aldrig ækvivalere, hvad han eller hun har modtaget i ydelser. Nogle vil betale mere, end de vil få. Andre vil nyde betydeligt mere, end de nogensinde vil komme til at yde. Sådan er spillereglerne i den distributive reciprocitets system; men det stiller krav til den enkelte om at udvise solidaritet.

Hvis ikke der er en direkte sammenhæng mellem ydelse og nydelse, er der et element af systemisk 'altruisme', som består $i$, at man accepterer, at man som skatteborger meget vel kan komme til at betale betydeligt mere, end man nogensinde vil få igen. Det er det element, Jørn Henrik Petersen har betegnet som velfærdsstatens kærlighedsnorm, dvs. at man som borger er forpligtet på ansvarlige handlinger over for andre uden smålig hensyntagen til, hvad disse andre har gjort eller fremtidigt vil kunne gøre for en selv. Der er ikke tale om et noget-for-noget-princip, men derimod om et noget-for-ingenting-princip $(2004,68)$. Påstanden er, at velfærdsstaten som system ikke kan overleve, hvis ikke der er nogle, som i en besindelse på den større samfundsinteresse accepterer at yde betydeligt mere end andre. Der kan, som f.eks. Velfærdskommissionens afslutningsrapport til fulde dokumenterer, være en ulighed mellem generationerne, hvor en generation kan komme i en situation, hvor den af hensyn til sine efterkommere må udvise en større grad af solidaritet end den generation, som gik umiddelbart forud. Naturligvis kan man bringe det argument på bane, at et sådant krav om økonomisk 'selvopofrelse' hos en enkelt generation er helt rimeligt, når man tager det demografiske underskud i betragtning. Generationen har ikke reproduceret sig selv $\mathrm{i}$ en grad, så dens efterkommere er i stand til at løfte byrden efter dem. Men at dømme ud fra den aktuelle debat er der ikke stor lydhørhed for en sådan argumentation hos den berørte vælgergruppe. Det får være, hvad det er; men der kan som bekendt nævnes andre områder, hvor en solidarisk eller 'selvopofrende' indstilling er påkrævet.

Det gælder i relation til forskellige befolkningsgrupper, der som f.eks. handicappede, flygtninge, etc. ikke har den samme mulighed for at yde deres bidrag til det fælles 
gode, som andre mere velstillede befolkningssegmenter har. Det gælder på et individuelt niveau, hvor vi hver især er udstyret med forskellige arbejdsevner og talenter, og det er derfor helt rimeligt, at man hver især efter bedste evne forvalter det pund, man fik givet. Nogle vil i det samlede regnskab yde væsentligt mere end andre. Og sådan må det nødvendigvis være, eller hvad?

Man kan naturligvis hævde, at denne forskel i evner og arbejdsindsats i høj grad tilgodeses gennem forskellen i indkomst, der netop honorerer vores forskellige ydeevne; men den er åbenbart, som en række aktuelle politiske debatter tydeligt viser, ikke i sig selv tilstrækkelig til at hindre diskussioner om sammenhængen mellem ydelse og nydelse. Når f.eks. den siddende regering har set det som fordelagtigt at indføre et skattestop, er det blandt andet et udtryk for, at de grupper, der for alvor bidrager til skattebetalingen, ikke føler, at de gennem deres løn får tilstrækkelig kompensation for deres større arbejdsindsats, evner og ansvar. De oplever, at sammenhængen mellem ydelse og nydelse er truet, fordi de betaler betydeligt mere, end de får igen. Det peger imidlertid på et grundlæggende problem for velfærdsstaten, hvis en væsentlig forudsætning for dens eksistens er, at der altid skal være grupper, som skal lægge mere i den fælles kasse, end de selv kan gøre sig håb om at få tilbage.

\section{Solidaritetskravet og troværdighedsproblematikken}

Hvis velfærdsstaten som samfundsstruktur forudsætter en ikke ringe grad af solidarisk adfærd og 'selvopofrende' villighed - hos nogle - til asymmetriske bidrag, rejser det det spørgsmål, hvordan den overhovedet kan gøre en sådan fordring gældende? Det er i den sammenhæng, jeg bringer Naphta og kristendommen på banen; men det skal understreges, at min argumentation på ingen måde udelukker, at alternative verdenssyn som andre religiøse tydninger eller en humanisme også kan understøtte den solidaritet eller 'selvopofrende' adfærd, jeg taler om, og virke betydningsstabiliserende for velfærdsstaten. ${ }^{5}$ Mit anliggende her er alene at fokusere på kristendommens særlige bidrag til den moderne velfærdsstat, ligesom jeg vil hævde, at den som religiøs verdensanskuelse har en række fordele i sammenligning med en ikke-religiøs verdenstydning (jf. Petersen 2002).

Hvis spillereglerne i den distributive reciprocitet indebærer, at nogle skal betale mere, end de vil få, stiller det selvsagt krav til den enkelte om at udvise solidaritet. Den kan imidlertid være vanskelig at begrunde, fordi systemets symbolske orden ikke har andet end sig selv at henvise til. Som borger skal jeg udvise solidaritet, fordi det er en forudsætning for velfærdsstatens beståen; men der er intet, som tilskynder mig til det, hvis det indebærer en betydelig diskrepans mellem min ydelse og min nydelse. Vi har da også hyppigt set, hvor vanskeligt det er for politikerne at trænge igennem med et budskab til vælgerne, der indebærer, at de af hensyn til kommende generationer bør afstå fra opnåede rettigheder. Incitamentet her er naturligvis, at man som bedsteforældre

\footnotetext{
${ }^{5}$ Jf. Eco (1999, 91-3), der netop klandrer Martini for at indskrænke forpligtetheden på fjendekærlighed, næstekærlighed og selvopofrelse til kristne.
} 
eller forældre bør give afkald på egne privilegier af hensyn til ens børnebørn eller børn. Hvis ikke man er villig til at give afkald, pålægger man dem en fremtidig byrde. Et ræsonnabelt synspunkt, hvis indlysende fornuft imidlertid har vanskeligt ved at vinde gehør i den del af vælgergruppen, som skal give afkald på de pågældende privilegier efterlønsdiskussionen taler sit tydelige sprog.

Ser man bort fra, at en del af befolkningen aldrig vil komme i forældrerollen og derfor vil have vanskeligt ved at se, hvorfor netop de bør give afkald på egne privilegier af hensyn til fremtidige generationer, møder man igen anonymiseringens problem. Systemet er blevet så komplekst, at den enkelte ikke kan vide sig sikker på, at der vil være en direkte sammenhæng mellem hans eller hendes given afkald på egne rettigheder og vedkommendes børns senere opnåelse af en mere begunstiget tilværelse. Det er derfor en argumentation, der har vanskelige kår, men som samtidig understreger det føromtalte grundproblem i velfærdsstaten. Jørn Henrik Petersen har i den tidligere omtalte essaysamling skildret det på den måde, at det for den enkelte "er rationelt at følge de små klogskabsregler og ikke opføre sig efter de spilleregler, velfærdsstaten forudsætter. Thi da bliver man snydt" $(1996,36)$. Men hvad nu hvis denne form for snyd faktisk er indbygget $i$ systemet på en måde, så det kun kan fungere under forudsætning af, at der er nogle, som i fællesskabets interesse accepterer at lade sig snyde og udnytte i den forstand, at de yder mere, end de nyder? Hvorfor skal jeg udvise solidaritet og handle 'selvopofrende', hvis ikke det kommer mig selv og eventuelt mine til gode?

\section{Velfærdsstatens raison d'être}

Den danske velfærdsstat har, fornemmer jeg, et problem, når den skal have sine borgere til $i$ handling at vedgå, at solidarisk adfærd er en forudsætning for dens fortsatte beståen. Velfærdsstaten har meget vanskeligt ved at give et tilstrækkeligt bæredygtigt svar på, hvorfor det er nødvendigt, at bestemte grupper bidrager med betydeligt mere til systemet, end de vil få igen. De forsøg, der, jf. f.eks. John Rawls i A Theory of Justice, har været gjort på at formulere en etik på sekulariseringens præmisser, som ikke alene legitimerede solidarisk adfærd, men også søgte at argumentere rationelt for dens betydning, kommer i sidste ende til kort, fordi de ikke har en absolut eller ekstern instans at henvise til. Hvorfor skulle jeg dog som tankeeksperiment placere mig bag et uvidenhedens slør, hvis min øjeblikkelige situation på ingen måde lader antyde, at jeg på et tidspunkt vil blive ramt af en kontingent oplevelse, der placerer mig i gruppen af socialt og kulturelt marginaliserede medmennesker? Man kan appellere til storsind, generøsitet, offervilje, nødvendigheden af asymmetriske bidrag etc. hos den enkelte, fordi det gavner almenvellet; men egentligt forpligtende kan det aldrig blive. Man kan gardere sig mod de værste former for overgreb og misbrug af velfærdsstaten gennem kriminalisering af bestemte handlinger, men man kan ikke gennem lovgivning påtvinge folk en bestemt form for tænkning, som tilskynder dem til den form for solidarisk adfærd, der er en forudsætning for velfærdsstatens beståen. Det er netop en pointe hos Løgstrup i hans sondring mellem fuldbyrdelsen af næstekærlighedsbuddet i den nære 
relation mellem enkeltindivider og dets omsætning i en politisk ide, der skal kunne gøres gældende på samfundsniveau.

Det ville, hævder Løgstrup, være udtryk for sværmeri at indrette samfundet på en måde, der skulle give borgerne lejlighed og råderum til at elske næsten. Man kan ikke ved lov fremtvinge et bestemt sindelag, men man kan indrette samfundet "på en sådan måde, at den magtfulde tvinges til at omgås sin magt, som om han havde fået den til at tjene andre med" $(1996,51)$. Det sker gennem sekulariseringen eller nedskrivningen af næstekærlighedsbuddet i skikkelse af den gyldne regel: "Gør vi politisk brug af kærlighed til næsten som idé, er der ingen, der elsker næsten, men der er nogen, der tvinges til at bære sig ad, som om de gjorde det" $(1996,54)$. Det er, som Løgstrup også gør opmærksom på, den forudsætning, der ligger bag forsøgene på økonomisk udligning mellem samfundets forskellige samfundsgrupper. Men hvad betyder det $\mathrm{i}$ forhold til de eksempler, vi har kigget på i den forudgående diskussion?

Løgstrups argumentation er - om end formuleret på et helt andet grundlag og ud fra ganske anderledes forudsætninger - beslægtet med Rawls'. Den moderne velfærdsstat er indrettet ud fra den gyldne regel: Man skal handle mod den anden, som man vil, at den anden skal handle mod en selv. Det kræver, hævder Løgstrup, et fantasielement, fordi man skal kunne sætte sig i den andens sted. Der er ikke tale om et noget-for-nogetprincip, fordi ens handlinger ikke er begrundet $i$ erfaringen af, hvad den anden har gjort mod en selv, men derimod i hvad man kunne ønske gjort mod sig selv, hvis man var i den andens sted. På samme måde som man hos Rawls skal placere sig bag det uvidenhedens slør, der tilsiger, at man kunne have været eller kunne komme i den andens position, skal man hos Løgstrup fantasere sig til, hvad man ville have ønsket gjort mod sig selv, hvis man havde været i den andens situation (1996, 53). Omsættes denne forståelse, som det er sket i den danske velfærdsstat, i en samfundsdannelse, betyder det, at den afstand, mange borgere kan konstatere mellem ydelse og nydelse, legitimeres af den tankeoperation, som sætter den enkelte i stand til at fantasere sig ind $\mathrm{i}$ den andens situation.

Løgstrup er ikke så naiv, at han forestiller sig, at man ad den vej skulle kunne fremelske et næstekærligt sindelag hos velfærdsstatens borgere. Han anerkender, at de stærke vil skære tænder, når deres indtægt beskæres til fordel for de ringere stillede, men hans påstand er netop, at det er uden betydning. Systemet skal indrettes på en sådan måde, at det ikke forudsætter næstekærlighed mellem borgerne, men alene at de tvinges til at opføre sig, som om de nærede denne kærlighed til hinanden, velvidende at de ikke gør det $(1996,54)$. Det er alt sammen udmærket, men det efterlader igen spørgsmålet, hvad man gør i en situation, hvor et stadigt stigende antal borgere vægrer sig ved at overholde de helt basale spilleregler, der er en forudsætning for velfærdsstatens beståen. Hvad gør man i en sammenhæng, hvor de politikere, der i lovgivning er ansvarlige for at håndhæve og løbende tilpasse systemet, afstår fra at foretage en række nødvendige velfærdsindgreb af frygt for store vælgergruppers protest? Hvis det populistiske demokrati har vundet gennemslagskraft, hvad holder da systemet fast på de principper, der er en forudsætning for dets eksistens? Hvad sikrer systemets fortsatte forpligtethed 
på tanken om, at de velbjergede tvinges til at handle, som om de elskede de mindre velbjergede?

Det er i den sammenhæng, vil jeg hævde, en religiøs verdenstydning kan bidrage positivt til velfærdsstatens sammenhængskraft og sikre den mod opløsning, fordi den som religiøs tolkning ikke tillader relativeringer eller gradbøjninger af ens pligt over for medmennesket.

\section{Kristendommens bidrag til den moderne velfærdsstat}

Det er velkendt, at den skandinaviske velfærdsmodel har kristendommen som en væsentlig åndshistorisk forudsætning (jf. Østergaard 2005). Uden at behandle intentionerne bag velfærdsstatens udvikling, som meget vel kan være en følge af magtgruppers interesser, er det ikke urimeligt at betragte den som et sekulariseret forsøg på at omsætte et kristent værdiunivers i en moderne samfundspraksis. Det var, som vi så, en hovedpointe i Løgstrups opfattelse. Denne samfundspraksis har imidlertid den principielle adskillelse mellem religion og politik som forudsætning. Heri ligger dens Akilleshæl.

Det kristne betydningssystem og de udvekslinger, det sætter som ideale, har en instans uden for verden, uden for dennesidigheden at henvise til. Det kan ingen rød fane konkurrere med, uanset hvor ideologisk tæt den kan komme på religion i øvrigt. Når man $i$ en hensyntagen til en svagere part, tilskyndes eller formanes til at tilsidesætte egne behov til gavn for næsten, er det begrundende forbillede Guds handlen med mennesket. Anderledes med velfærdsstaten, hvis ideologiske fundament i sagens natur må være selvreferentielt. Vil man argumentere for solidariske handlinger, kan det kun ske, som det f.eks. finder udtryk i Rawls' tanke om uvidenhedens slør eller i Løgstrups tale om fantasielementet i rolleombytningen, med henvisning til, at man selv kunne komme $\mathrm{i}$ en tilsvarende situation. Al erfaring tilsiger os imidlertid, at den slags ræsonnementer er mere end vanskelige at omsætte $i$ en konkret praksis, hvor mennesket i specifikke situationer kan gradbøje en hvilken som helst fordring, så den i stedet fremmer den selvnyttige eller egenkærlige adfærd.

I det konkrete møde med den årlige selvangivelse kan det være vanskeligt at bevare det solidariske overskud, som tilsiger, at ens ydelse ikke nødvendigvis skal komme tilbage som direkte nydelse, men at den i stedet skal være den svagere part til gavn, i hvis sted man med sin fantasi kan sætte sig. Man behøver ikke, som det blev pointeret af Løgstrup, at betale sin skat med glæde. Man er i sin gode ret til at skære tænder, når blot man overholder de spilleregler, der er en forudsætning for systemets beståen. Hvis skattebetalingen imidlertid bliver et springbræt for alskens fiflerier, er der et problem for den velfærdsstat, som ikke nødvendigvis kræver borgerens samtykke i sind, men dog i gerning. Det truer membranen, hvis de gerninger, der var ment som midlet til den politiske gennemførelse af den gyldne regel i en samfundspraksis, i stedet bliver et instrument $i$ borgerens kamp for at bjerge sig mest muligt til. Da har egennytten og selvkærligheden sejret ikke blot i sind, men også i gerning. 
I modsætning til denne verden, hvor alt kan relativeres og gøres til genstand for diskussion, sætter kristendommen en absolut instans, mennesket må bøje sig for. Alle har vi noget på hinanden, og derfor kan min ugerning altid reduceres til et svar på den andens overtrædelse. Fifler jeg, kan jeg forsvare det, eftersom min nabo nok også udnytter systemet. Alle har vi noget i klemme, alle kan vi undskylde os; men for Gud har vi ingen undskyldning, og det er afgørende. Det gælder her, hvad Søren Ulrik Thomsen et sted har fremhævet, at "fordi vi alle sammen har noget på hinanden og hver især en hel del i klemme, er den enkelte nødt til at tugte sig ved at forholde sig til en instans, der ligger uden for den sociale tam-tam" (Thomsen 2001, 9). For Gud er mit hykleri og fifleri en synd mod næsten og derfor også en synd mod Gud. Den kan hverken bortforklares eller relativeres - højst tilgives. Ligesom erkendelsen af småsmart opførsel som synd bliver en tugtelse, på samme måde tjener den kristne indprentning af værdier som hensynsfuldhed, selvopofrelse og solidaritet til en dannelse i menneskelighed. Samtidig er de med til at holde et system i skak, der er blevet til gennem en nedskrivning eller sekularisering af disse idealværdier. Kristendommen kan ikke fordre af velfærdsstaten, at den på nogen måde skulle forpligte sig på en efterlevelse eller fuldbyrdelse af det kristne værdiunivers. Det ville blot betyde genindførelsen af et teokrati og en utopisk forestilling om, at man skulle kunne fremelske et bestemt sindelag hos borgerne. Kirken kan derimod i en besindelse på adskillelsen mellem religion og politik bidrage positivt til velfærdsstatens sammenhængskraft. Hvis velfærdsstatens grundlæggende værdier er sekulariserede versioner af kristne idealværdier, har kristendommen en vigtig mission ved til stadighed at holde idealerne op over for den enkelte og over for samfundet, så man ikke i den realpolitiske verden stiller sig tilfreds med tingenes tilstand eller fristes til at udhule velfærdsstatens fundament. Kirken er en røst, som, fordi den står uden for systemet, kan kritisere magthavere og de enkelte borgere for ikke i tilstrækkelig grad at honorere den gyldne regel som samfundspolitisk ide, ligesom den kristne forkyndelses absolutte fordring til den enkelte kan være en vigtig kilde til selvkritik i ens gøren og laden i verden og i ens politiske stillingtagen. Hvis den danske velfærdsstat som system er indrettet sådan, at borgerne skal leve, som om de efterkom den gyldne regel, er det vigtigt, at der er en instans uden for systemet, som kan holde borgere og system forpligtet på denne efterlevelse.

\section{Naphtas ret}

Nogle vil givetvis indvende, at den religiøse svøbe, jeg i det forudgående har hævet over velfærdsstaten, tilhører verden af i går. En verden, hvor kristendommens krav til mennesket endnu kunne opleves som forpligtende; at en religiøs fordring i dag er lige så udhulet som alt muligt andet; og at min argumentation i bedste fald har karakter af en nostalgisk længsel efter et idealt samfund, der alligevel altid kun har fristet en utopisk tilværelse i en teologisk elites luftkasteller. Et samfund, der aldrig har eksisteret, fordi en konkret samfundsdannelse altid vil rumme konflikten mellem praksis og ideologi, modsætningen mellem fifleriet og den ideale adfærd, og netop derfor bestandigt vil have indbygget en række profylaktiske værn, der skal sikre snyderiet og fifleriet mod at blive 
alt for omsiggribende. Det er muligt. Ikke desto mindre vil jeg også på dette punkt fremhæve kristendommens bidrag til velfærdsstatsdiskussionen.

Hvis jeg frygter for at blive taber i den distributive reciprocitets komplekse spil, hvorfor så ikke bare erkende, at sådan er verden nu en gang indrettet, og så i øvrigt spille de kort, jeg har på hånden, i håbet om at blive vinder. Hvorfor anklage i stedet for helhjertet at overgive sig til spillet? Hvorfor forarges i stedet for at overbyde i udnyttelse, snyderi og fifleri? Det kan, som Naphta lader forstå, en religiøs fortolkning give en forpligtende forklaring på. En verdensanskuelse, der i sin selvforståelse henter sin begrundelse et sted uden for verden, uden for historien, og som derfor kan rejse absolutte krav til mennesket. Deri ligger også dens styrke i forhold til sekulære verdensanskuelser, der lægger vægt på en række af de samme værdier, men alene kan argumentere for dem ud fra et fornuftsbegreb. Eller som Kardinal Martini skærpet formulerer det $i$ et bidrag $i$ den tidligere omtalte essaysamling med skyldig henvisning til Hans Küng: "Kun det ubetingede selv formår at forpligte ubetinget; kun det absolutte at binde absolut" (1999, 77).

Min påstand er ikke, at velfærdsstaten som system kun kan eksistere under forudsætning af en kristen 'overbygning', som funderer systemets sekulære etik i kristne idealværdier. Tanken er mere moderat, at kristendommen som religiøs verdensanskuelse kan bidrage positivt til velfærdsstatens sammenhængskraft, dels fordi den kan være en kritisk røst over for systemet, dels fordi den over for de borgere, som også har kristendommen som del af deres verdensanskuelse, kan legitimere og forankre velfærdsstatens grundlæggende værdier i det kristne betydningssystem. Hvis omgåelse af systemet ikke kun opfattes som udtryk for fifleri, men også som en synd mod medmennesket og dermed mod Gud, skærpes kravet til den enkelte borger. Tilsvarende gælder det positivt. Det er til almen benefice for velfærdsstaten at have borgere, hvis religiøse verdenssyn tilsiger dem, at de i radikal forstand skal fuldbyrde næstekærligheden. Sådanne borgere har en yderligere tilskyndelse til at acceptere og efterleve et system, der forudsætter, at de som borgere kan komme til at yde betydeligt mere, end de nogensinde vil komme til at nyde.

Som fremhævet gælder min argumentation ikke kun i forhold til kristendommen, men også i forhold til andre religiøse tydninger under den forudsætning, at de dels accepterer den principielle adskillelse mellem politik og religion, dels at de værdier, de plæderer for, modsvarer velfærdsstatens grundlæggende principper. Velfærdsstatens sociale kohærens står og falder med dens enkeltmedlemmers tilslutning til dens grundlæggende værdiunivers; men den er sårbar, fordi den ikke har andet end sig selv at henvise til. I den sammenhæng kan religion - og i denne kontekst kristendom - bidrage positivt til dens sammenhængskraft, fordi den supplerer eller komplementerer de basale værdier og principper, som velfærdsstaten er bygget op om, ved at forankre dem i en religiøs tydning, der ikke tillader relativeringer. 


\section{Litteratur}

ECO, UMBERTO

1999 "Wenn der andere ins Spiel kommt, beginnt die Ethik", in: Carlo Maria Martini \& Umberto Eco, eds., Woran glaubt, wer nicht glaubt?, Deutscher Taschenbuch Verlag, München (italiensk originaludgave 1996), 82-93.

GEERTZ, ARMIN W.

1996 "Begrebet religion endnu engang - et deduktivt forsøg", Chaos 26, 109-28.

JOHANSEN, JøRGEN DINES \& SVEND ERIK LARSEN

1994 Tegn i brug, Amanda, Ålborg.

LøGSTRUP, KNUD E.

1996 Etiske begreber og problemer, Gyldendal, København.

Martelli, Claudio

1999 "Das weltliche Credo des christlichen Humanismus", in: Carlo Maria Martini og Umberto Eco, eds., Woran glaubt, wer nicht glaubt?, Deutscher Taschenbuch Verlag, München (italiensk originaludgave 1996), 128-42.

MARTINI, CARLO MARIA

1999 "Woher leuchtet das Licht des Guten", in: Carlo Maria Martini \& Umberto Eco, eds., Woran glaubt, wer nicht glaubt?, Deutscher Taschenbuch Verlag, München (italiensk originaludgave 1996), 74-81.

Petersen, Anders KlostergaArd

2002 "Kristendom og sund fornuft", in: Niels Grønkjær \& Henrik Brandt-Pedersen, eds., Interesse for Gud. Ni tidssvarende essay, Anis, Frederiksberg, 134-50.

2004 "Divina Oeconomia", in: Anker Brink Lund, Janne Normann \& Anders Klostergaard Petersen, eds., Kcere samfund. En debatbog i anledning af Jørn Henrik Petersens 60 års fødselsdag, Odense Universitetsforlag, Odense.

2005a "Fra skizofreni til balkanisering. Troen som en blandt andre virkelighedsverdener", Fønix 29 (2), 112-31.

2005 b "Religiøs modenhed eller Sancho Panza til hest", Psyke \& Logos (Udviklinger $i$ voksenlivet) 26 (2), 543-58.

Petersen, JøRn HENRIK

1996 Vandringer $i$ Velfcerdsstaten. 11 bidrag om velfcerdsstatens legitimitet, Odense University Studies in History and Social Sciences 197, Odense University Press, Odense.

2004 "Velfærdsstatens krav til dig!", in: Jørn Henrik Petersen \& Klaus Petersen, eds., 13 Udfordringer til den danske velfcerdsstat, Syddansk Universitetsforlag, Odense, 61-75.

RAPPAPORT, ROY A.

1999 Ritual and Religion in the Making of Humanity, Cambridge Studies in Social and Cultural Anthropology 110, Cambridge University Press, Cambridge.

RAWLS, JOHN

1972 A Theory of Justice, Oxford University Press, Oxford.

STJERNFELdT, FrEDERIK \& THOMSEN, SørEn ULRIK

2005 Kritik af den negative opbyggelighed. 7 essays af Frederik Stjernfeldt og Søren Ulrik Thomsen, Vindrose, København.

THOMSEn, Søren ULRIK

2001 "Kraft durch Schadenfreude", Politiken 17. marts, 4. sektion, 8-9.

VEYNE, PAUL

1983 Les Grecs ont-ils cru à leur mythes? Essai sur l'imagination constituante, Seuil, Paris. 
ØSTERGAARD, UFFE

2005 "Lutheranismen og den universelle velfærdsstat", in: Jens Holger Schjørring \& Jens Thorkild Bak, eds., Velfaerdsstat og kirke, Anis, Frederiksberg, 147-84.

Anders Klostergaard Petersen

Lektor, cand.theol.

Afdeling for Religionsvidenskab Aarhus Universitet 